\title{
The determinants of China's foreign direct investment in Central Africa: evidence from the Republic of Congo and DRC
}

\author{
By Claude Sumata ${ }^{\mathrm{i}}$, Théophile Dzaka-Kikouta ${ }^{\mathrm{ii}}$
}

\section{Introduction}

Since the 1990s, mainly through multinational corporations (MNCs), foreign direct investment (FDI) from South-South regions has been growing faster than FDI flows from North-South regions. In the framework of South-South investments, beside other rising Asian economies (India and the Persian Gulf countries) China is an important source of FDI to Africa. Within the African continent itself, South Africa remains the main actor in this context by first channelling investments into the Southern African region then other African countries.

Among the emerging markets is China, which ranks first as a donor, trading partner and investor country in Africa. This tends to reinforce China's supremacy in Central Africa, as the country is pursuing its appetite or hunger for resources, mainly oil and minerals, despite the financial crisis that erupted in 2008. This strategy seems to be twofold: there is a need in China to secure resources at home

${ }^{i}$ Claude Samata is Professor of Economics at the Catholic University of Congo, in the Democratic Republic of the Congo.

${ }^{i i}$ Théophile Dzaka-Kikouta is an Economic PhD at the Ngouabi University of Brazzaville, in Congo Brazzaville. He is also a Guest Researcher at BETA, at the University of Strasbourg, in France. 


\section{AFRICAN \\ EAST-ASIAN \\ AFFAIRS \\ THE CHINA MONITOR}

in order to sustain its economic growth and secondly there is a need for access to overseas markets for broader investments through Chinese companies.

China's involvement in the Republic of Congo and the Democratic Republic of the Congo (DRC), tends to be at the forefront of many analyses (Alden \& Davies, 2006; Wang, 2009; Jansson, 2009; Jansson 2013; \& Dussauge, 2010) in attempting to assess the dynamics of current Chinese Official Development Assistance (ODA) and foreign policy. It is worth mentioning that China's FDI seems to expand considerably in this context and its quest for natural resources seems to follow the same pattern. Another point is the fact that several western countries have raised concerns about the lack of transparency of this dealings and the risk to debt owed them by most developing countries as a direct consequence of this strategy. They seem to raise in this context the self-interest of China and to challenge the real motivations behind its foreign policy. A study by Foster et al (2008) tends to highlight the fact that China is playing a major role in financing main infrastructure projects in sub-Saharan African countries, including investments in oil and mining, through the famous "Angola mode", a sophisticated system of compensation, linking infrastructure programme with oil and other mineral resources.

Therefore, the purpose of this study is to analyse to what extent Chinese FDI in Central Africa contributes to improving the attractiveness of the host country. It supports the hypothesis that FDI should be empowered through appropriate economic and political governance by recipient countries. In fact, this study is expected to bring new insights and contribute to their sustainable development.

The outline of the study is as follows. The first section deals with the literature review on the motives and strategies of Chinese multi-national companies. Section two focuses on the setting of Chinese MNCs in Central Africa. Section three analyses the impact of the 2008 global economic crisis on Chinese FDI destinations in Central Africa. Section four concludes the paper and draws some policy implications by paying special attention to the opportunities offered by Chinese 
FDI for sustainable development of recipient countries in Central Africa.

\section{The determinants of the Chinese MNCs: theoretical background}

The majority of work on the motives of FDI refers to the four main determinants: firstly, the search for natural resources (resource-seeking); secondly, the search for the markets (market-seeking); thirdly, the search for strategic assets (strategic asset-seeking) to acquire technology, managerial capacities, brands, distribution networks and other assets and lastly, the search for efficiency (efficiency-seeking) to exploit economies of scales, or by securing access to cheaper inputs.

In 2006 and 2009 the United Nations Conference on Trade and Development (UNCTAD) World Investment Report identified three main purposes fuelling FDI from emerging economies to developing countries. As emphasised in the 2009 UNCTAD World Investment Report, "companies and funds from a number of Asian economies that are not, or are less, affected by the financial turmoil may maintain an aggressive strategy for overseas investments and become more important actors on the global FDI scene. Furthermore, for many Chinese and Indian companies in particular, the desire to acquire undervalued assets (such as mineral deposits, technologies, brand names and/or distribution networks) during the global and financial crisis may boost Asian Investments in developed countries" (UNCTAD, 2009).

According to the 2009 UNCTAD World Investment Report on Chinese FDI, trans-national companies (TNCs) are driven by their need to invest abroad in order to secure access to natural resources (oil, gas and mineral deposits) and create assets (technologies, brand names and distribution networks). There has also been a growth in FDI flows to low-income African countries. In 2008, for example, Asian countries' investments in infrastructure projects in sub-Saharan Africa rose significantly. From 1990 to 2008, Asia's weight in African trade doubled to 28 per cent. They play a crucial role in financing infrastructure in 


\section{AFRICAN \\ EAST-ASIAN \\ AFFAIRS \\ THE CHINA MONITOR}

lesser developed countries, such as Angola and the Democratic Republic of the Congo.

It could be argued that the search for natural resources was the main motivation of Chinese outward foreign direct investment (OFDI) since the country has committed to invest abroad and the strategy was also mainly fuelled by the exceptional economic growth of mainly China, during these past decades. In this context, Chinese MNCs have targeted some specific countries in Africa and Latin America, richly endowed with natural resources to fulfil their needs of natural resources. The bulk of Chinese FDI in Africa are mainly channelled through state owned enterprises (SOEs) looking for untapped reserves of natural resources, often by linking these investments with ODA programmes and trade. Among the African countries targeted, we can mention those facing an unstable political environment (Sudan, DRC, Angola, Zimbabwe, Niger, GuineaConakry; and so on).

Under these circumstances, China does not seem to avoid the troubled areas at risk in order to increase the volume of its OFDI. In some cases, unlike its Western competitors, the Chinese state-owned MNCs have benefited from cheap capital in connection with long-term strategies. In fact, Western companies tend to consider the political instability in African countries as a constraint and this risk assessment tends to limit the opportunity to achieve high levels of FDI (Alden and Davies, 2006).

Taking on board the fact that SOEs constitute the main actors driving overseas Chinese FDI, investment decisions also reflect the political objectives beyond the will of profit maximization. The expansion of Chinese FDI seems to be fuelled by the search for export markets (market-seeking) as FDI flows into China from developed countries have intensified over the past decades. The main reason for this type of FDI by Chinese MNCs is the intense competition faced by Chinese firms in the domestic market, due to the massive entry of FDI into the Chinese market, especially since China's entry into the World Trade Organi- 
sation, in 2001 (Brautigam, 2009).

However, one can argue that the competition is not only brought by foreign companies into China but also Chinese companies themselves. Consequently, this situation creates many setbacks such as saturation of the Chinese market and lack of financial support, mainly for private companies.

For several years, China has been the largest FDI recipient country among the emerging countries, with US\$ 108 billion in 2008 (UNCTAD, 2009). In some cases, the search for export markets is consistent with the strategy deployed by Chinese MNCs to enjoy the benefits of preferential access offered by some countries in order to target developed countries' markets (for example, invest in Turkey to enter the European Union market) or invest in Africa to benefit from preferential agreements [for instance African Growth and Opportunity Act (AGOA); and Economic Partnership Agreements (EPAs) especially for textiles and clothing] to access developed countries' markets

The third motive is related to the search of strategic assets (strategic assetseeking), and one can mention that unlike the multi-nationals from developed countries, Chinese companies seem not to rely on specific major assets (brands, patents, innovative production processes; and so on). In this context the main difference between the internationalisation of Chinese and the Japanese firms in the 1980s needs to be analysed. While the latter benefited from time to build specific assets: brands (Toyota, Mitsubishi, Sony), technological innovation and dominant domestic market positions, Chinese firms were able to establish, hybrid operations such as partnerships and strategic alliances. These operations, with a remarkable pragmatism and experience in the domestic market, reconciled their financial and technological resources with their international strategy ambitions, while limiting their risk-taking.

\section{The dynamics of the Chinese FDI in Central Africa}

In this section we will identify trends in regional distribution of Chinese FDI, 


\section{AFRICAN \\ EAST-ASIAN \\ AFFAIRS \\ THE CHINA MONITOR}

motives and strategies applied in the context of the Economic Community of Central African States (ECCAS) and deduce the implementation of Chinese infrastructure projects and territorial attractiveness in Central Africa.

\subsection{Trends and structure of the Chinese FDI}

Notwithstanding the problem of data sources, most studies agree that the Chinese FDI has become significant after 2000. The annual average FDI outflows over the period 1990-2000, were only US\$2.1 billion, reaching US\$ 56.5 billion in 2009. It is expected that FDI will continue to increase given that China continues to accumulate large current account surpluses and huge foreign exchange reserves. Since 2007, China created a sovereign wealth fund managed by the China Investment Corporation (CIC) with a capital of US\$ 200 billion, fuelled by a partial transfer of the reserves of the central bank. The aim was to ensure the setting of a more active use of its surplus via the diversification of its assets abroad. The CIC is working with the State Administration of Foreign Exchange (SAFE) related to the central bank. This public enterprise is responsible for managing the vast foreign exchange reserves by carrying on in its behalf overseas investments (Milelli et al. 2009).

There is some evidence to suggest that the Chinese FDI outflows weighed only one per cent of the world total in 2007. However, this share has nearly tripled to 2.8per cent in 2008 (Pairault, 2010). For some host countries, particularly in Afri$\mathrm{ca}$, the percentage of Chinese FDI sometimes accounted for more than ten per cent of the overall FDI to African countries. In terms of global FDI stocks, China's FDI accounted for US\$ 96 billion in late 2007, against just US\$ 29 billion for India which, is also a major emerging investor in Africa. Taking a geographic perspective of Chinese FDI destinations, it is clear that Asia remains the largest recipient with 50.4 per cent of the total Chinese FDI over the period 2003-2007, followed by Latin America and the Caribbean with 37.4 per cent (for a discussion of this percentage, see L. Avendaño in this issue). For its part, Africa is the third most important destination of Chinese FDI with 4.2 per cent, placing it before 
North America and Europe.

In late 2007, it is estimated that over 7000 Chinese MNCs invested across 173 countries around the world by creating at least 10000 companies abroad with almost 1000 operating in Africa and in addition, the share of Chinese FDI to Africa has grown steadily. Thus, for Brautigam (2009), using data from Ministry of Commerce of the People's Republic of China (MOFCOM), Chinese FDI share in Africa has more than doubled over five years from 2.6 per cent in 2003 to 6 per cent in 2007. For the same period, Berthélemy (2009) demonstrated that Chinese FDI to Africa grew faster than FDI from other countries.

In terms of sectoral distribution, based on data from MOFCOM, for the period 2002-2005, Huchet and Ruet (2008) highlighted that Chinese MNCs invest first in the primary sector: energy and raw materials (44 per cent), industry ( 26 per cent), services: trade, distribution, information and communications technology (ICT) (23 per cent) and in other areas such as infrastructure ( 7 per cent). Cheng and Ma (2008) note that in 2006, over 40 per cent of FDI inflows in China have been directed to the primary sector (oil and mining), 54 per cent to services (trade, finance, construction; etc.) and only 4 per cent went to manufacturing. The 2009 UNCTAD's World Investment Report highlighted the increase of Chinese FDI overall in the primary sector (agriculture, energy and mining), in connection with mergers and acquisitions in developed countries in 2008.

Among the top 20 African recipients of Chinese FDI, there are five countries in Central Africa exploiting crude oil and minerals: DRC, Congo Brazzaville, Equatorial Guinea, Gabon and Chad. Moreover, this list of the top 20 is dominated by 13 resource-rich countries, with the exception of Mauritius, Egypt, Ethiopia, Madagascar, Benin, Kenya andTanzania. However, in recent years, it appears from the Chinese data source (2009 Statistical Bulletin of China's Outward Foreign Direct Investment) that the distribution of Chinese FDI in Africa by sector tends to widen in favour of the manufacturing and the services sectors. 


\section{AFRICAN \\ EAST-ASIAN \\ AFFAIRS \\ THE CHINA MONITOR}

\subsection{Chinese FDI within the ECCAS: natural resources and export markets}

The search for natural resources is the major catalyst of the internationalisation of Chinese MNCs. This trend is corroborated by the situation of Chinese investments in Central Africa which are primarily intended for the oil and mining sectors. It appears that since the 2000 s, the three major Chinese oil companies with public capital all invested in oil-producing countries of Central Africa according to their specialisation: China National Petroleum Corporation (CNPC) (exploration and production on-shore), China Petroleum \& Chemical Corporation (SINOPEC) (refinery and petrochemicals) and China National Offshore Oil Corporation (CNOOC) (exploration and production offshore).

According to Alden and Davies (2006), Chinese oil companies in Africa deploy three types of managerial strategies. It would be primarily a procurement strategy and vertical integration. Furthermore, this would be an energy security strategy of the Chinese state that seeks acquisitions of energy assets abroad; particularly in Africa, Latin America and the Middle East. Therefore, the Chinese government directly supports its MNCs financially, and links that support to development projects (project aid) and possibly involves diplomacy with the political leaders of the target countries.

It would also be a strategy of partnerships and joint venture allowing Chinese companies to partner with local businesses and / or those of Western countries in foreign markets for technological and managerial learning. For instance the joint venture established in Angola between Sinopec (55 per cent) and the Angolan oil public enterprise, Sonangol (45 per cent) follows this pattern. Sinopec also acquired the Canadian group Addax, already established in Gabon and Congo Brazzaville for $\$ 7.2$ billion, to benefit from its expertise in offshore exploration in ultra-deep water. Sinopec has kept intact the new structure, keeping management and technical teams of Addax (Brautigam, 2009).

Beside oil, the Chinese state-owned MNCs are designed to ensure China's demand for mining products whose dependence vis-à-vis imports is growing. In this 
regard we know that among the worlds oil-consuming countries, China ranks second (10 per cent of the global oil imports in 2008) after the United States, which became a net oil importer in 1993. Currently Africa imports nearly 35 per cent of the worlds petroleum products (compared to 20per cent in 2005 and 9per cent in 1995). The pattern of the Chinese trade with African countries shows the significant weight of petroleum products ( 73 per cent), the rest being mainly made up of minerals (iron, copper, cobalt, manganese, platinum, diamonds; and so on.), and wood. In the case of the DRC, the mining sector seems to be at the forefront of Chinese FDI. In this context, Sicomines was established in 2008 in order to produce around ten million tons of copper and cobalt. With two-thirds of the investments owned by Chinese investors, it was expected to deliver at normal prices to China.

According to Beuret and Michel (2008), it is logical to China, with its 50 per cent dependence on imported oil, that out of the "top 20" African recipients of Chinese FDI, 90 per cent is in oil and mining products. In fact, the total Chinese imports from Africa amounted US\$ 55.8 billion in 2008. According to Wang (2009), among Chinas "top 10" African suppliers, there were five ECCAS countries that provided 57 per cent of Chinese imports from Africa: Angola (40per cent), Congo - Brazzaville (6.7per cent), Equatorial Guinea (4.1per cent), Gabon (3.2per cent), Democratic Republic of Congo (2.8per cent).

However, as part of the search for export markets, some Chinese companies have recently invested in Central Africa in the manufacturing and the services sector. In accordance with the general trend of Chinese FDI in the world, mergers and acquisitions (as opposed to creation ex nihilo) is the preferred mode of operation in the manufacturing sector in Central Africa. There are some geographic concentrations of Chinese FDI in the two countries in ECCAS with the highest GDP and populations, with more than 15 million people each: Angola (17 million inhabitants, GDP: US\$ 58 billion in 2007) and Cameroon (18.5 million, GDP: US\$ 20 billion in 2007). Both countries have a comparatively large 


\section{AFRICAN \\ EAST-ASIAN \\ AFFAIRS \\ THE CHINA MONITOR}

domestic market and have a relatively lower risk than other ECCAS countries. In fact, the size of their markets seems to be an asset in this context.

Similarly to the strategy adopted by CHA Group in Hong Kong specialised in textiles and clothing, the search for export markets constitutes a way to benefit from the preferential access policy helping African countries to penetrate Northern markets.

In other cases, the search for external markets is justified by the desire to develop a competitive technology adapted to the needs of host countries: the cases in point would be Chinese FDI in the automotive and electrical equipment sectors in Angola and in the metallurgy and motorcycles in Cameroon. Unlike the primary sector in which investments are of necessity, companies in the manufacturing sector are most often dispersed and are encouraged to have specific geographical location in order to benefit from external economies of scale.

Some evidence suggests that this strategy requires high quality infrastructure and well-trained human resources. Dzaka and Bitemo (2010) have shown for the period 1980-2002, that ECCAS countries endowed with oil and minerals were not attractive from this point of view for FDI in the manufacturing sector. Therefore the strategic importance of Chinese investments in the infrastructure building sector (roads, hospitals), made since the 2000 s, should be a fertile ground for growth and poverty reduction in the Republic of Congo and DRC.

\subsection{Implementation of Chinese infrastructure projects and territorial attractiveness in Central Africa}

\section{The "Angola mode" arrangement linking Chinese ODA and FDI}

The "Angola mode" arrangement is a complex process of compensation implemented by China to better manage risk countries in Africa. In fact, the recipient nation can change resources into cash to overcome funds shortages and develop its extractive industries. In many countries such as Angola, Congo - Brazzaville and the Democratic Republic of Congo, this strategy helps China's state-owned 
companies to secure resource-development rights in the recipient country. It links development aid, trade and investment by Chinese enterprises in host countries with significant oil and mineral resources.

According to many authors (Jansson, 2009 and 2013; Wang, 2009; DzakaKikouta, 2008 and 2009): no money is paid directly to African governments, but the Chinese government commissions a public construction firm which usually receives financial support from the Export-Import Bank (Exim Bank), to achieve infrastructure projects with the approval of African governments concerned (Davies, 2008). Therefore, in return for the provision of infrastructure,

Figure 1: Structure of “Angola mode" arrangement

\section{BENEFICIARY COUNTRY}

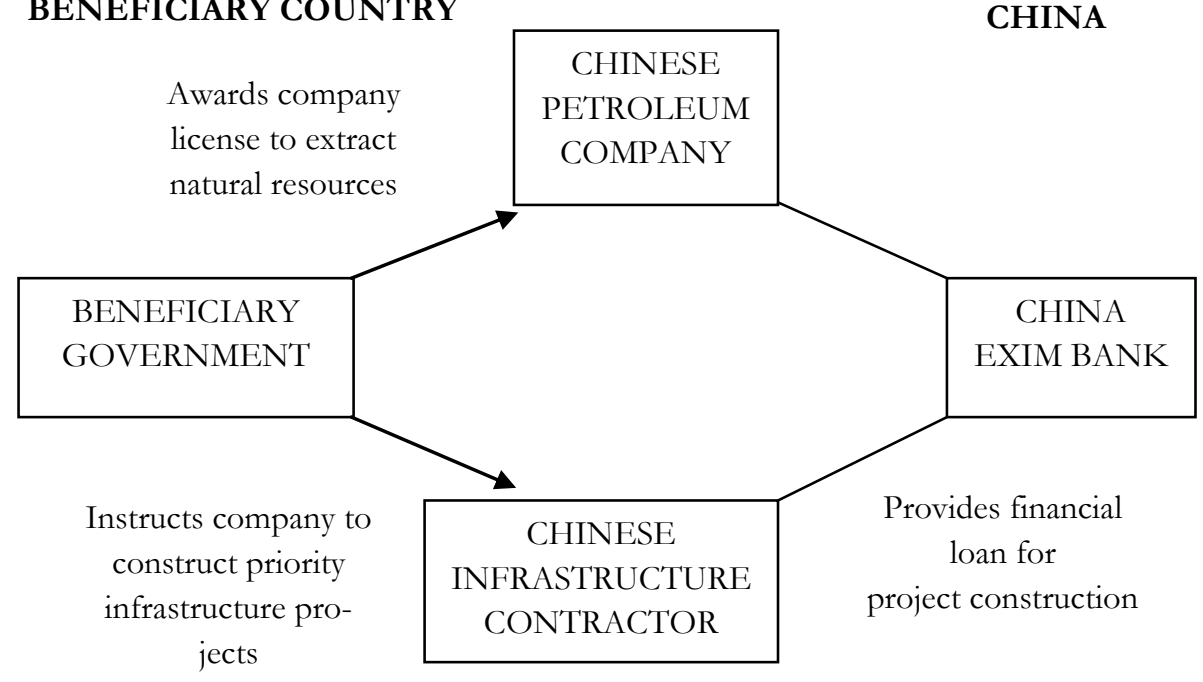

Source: Foster et al. 2008) 


\section{AFRICAN \\ EAST-ASIAN \\ AFFAIRS \\ THE CHINA MONITOR}

the African government gives Chinese companies the right to exploit natural resources in the host country, through the acquisition of shares in a public national form of joint venture or production licenses (see figure 1).

A consortium was established between Sonangol and Sinopec in 2006 allowing the Chinese group to secure its supplies of crude oil while fitting into a vertical integration strategy. In addition to the exploitation of crude oil, the construction of a second oil refinery in Lobito, the Sonaref, has been implemented; amounting US\$ 3.5 billion, as a joint venture between Sonangol (70 per cent) and Sinopec (30 per cent).

In exchange for these oil contracts, Angola has benefited from "soft loans", making China the first bilateral donor to Angola, particularly from the Exim Bank, to finance infrastructure projects mainly run by Chinese construction companies which acquired 70 per cent of the contracts against 30per cent for the local private sector.

Similarly, a concessional loan agreement between China and DRC worth US\$ 8.5 billion to the DRC was signed in 2007, based on the "Angola mode", namely infrastructure against mining contracts and joint ventures. Thus, Socomines, a mining joint venture company was formed, between the local public company, Gecamines (32 per cent) and a consortium of Chinese companies (68per cent) including China Railway Group Ltd, Synohydro Corporation, China Railway Sino-Congo Mining Ltd., Sinohydro Harbour Co Ltd, China Railway Resources Development Ltd.

In return for the loan of Exim Bank, China has been granted rights to exploit mineral resources (reserves of 10616070 tons of copper and 626619 tons of cobalt). According to this agreement the tonnage should be determined for all other valuable minerals. For 25 years, Socomines will produce nearly 10 million tons of copper and 60000 tonnes of cobalt worth US \$ 12 billion. In exchange US $\$ 6$ billion will be directed to infrastructure building for the DRC: rail (US \$ 3 billion) and road (US $\$ 2$ billion), social projects, including two universities, 
32 hospitals, 5000 social housing units (US \$ 758 million). The implementation of these projects by Chinese construction firms was expected to allocate between 10 to 12 per cent of the work to domestic enterprises in the DRC. In 2009 , this contract was amended to meet the requirements of the International Monetary Fund (IMF). Initially the Chinese side asked the DRC to secure the repayment of investments if the mining project does not make enough profit. This guarantee has been withdrawn.

Another example of application of the "Angola mode" arrangement is given by Gabon, where the consortium CMEC (Company of China National Machinery \& Equipment)/Sinosteel, benefiting from concessional financing from the Exim Bank has obtained since 2006 the sole rights to exploit iron in the Belinga region. This project represents an investment of US \$ 3.5 billion or 30 per cent of Gabon's GDP and the cost required to achieve the necessary infrastructure for the extraction of iron ore would amount to US\$ 590 million (Corkin, 2007). The FDI should generate about 30000 jobs in Gabon of which 80 per cent will be for Gabonese nationals. The China National Machinery and Equipment Corporation (CMEC) - the majority shareholder ( 85 per cent) in the joint venture and Gabon (15 per cent) - will build a $560 \mathrm{~km}$ railway between Santa Clara and Belinga (a deep water port on the Atlantic Ocean) and a hydropower dam to supply electricity mostly to the mining sector.

This project scheduled for 2011 was expected to last 20 years and exploit iron and other related products. China has committed to purchase all ore extracted from Belinga via a compensation contract.

In summary, this strategy seemed to be at the forefront of an unusual use of partnerships and joint ventures to secure access to raw materials. Chinese leaders were expecting to become co-owners of mines and oil fields in countries and businesses will flourish in this context according to the huge demand for resources (Dussauge, 2010).

There is a significant increase in trade and investment flows between Africa and 


\section{AFRICAN \\ EAST-ASIAN \\ AFFAIRS \\ THE CHINA MONITOR}

China since 2000. One can argue that China has rapidly modernising industries and burgeoning middle classes with rising incomes and purchasing power. This situation tends to push growing demand not only for natural resource-extractive commodities, but also for more diversified, non-traditional exports.

According to the current trend of China's investments, much of the accumulated stock of Chinese FDI in Africa is concentrated in extractive sectors, such as oil and mining. However, greater diversification of China FDI flows to Africa seems to occur today. Despite the immense growth in trade and investment between the two regions, there are significant asymmetries. While Asia accounts for one-quarter of Africa's global exports, trade between the two continents represents less than 2 per cent of the overall world exports to Asia.

The commitment by China in 2002 of a US\$ 2 billion loan for investment in Angola has made 'the middle kingdom' one of the most significant players in the Angolan rebuilding process. China's co-operation with Angola after the nightmare of its independence in 1975 followed the pattern of assisting National Union for the Total Independence of Angola (UNITA) as the People's Movement for the Liberation of Angola - Labour Party (MPLA) was siding with Moscow within the "Cold War". Afterwards, Angola like many African countries managed to maintain commercial relationship with Beijing.

\section{Infrastructure projects and knowledge transfer process}

A study by the Centre for Chinese Studies in Stellenbosch (2007) emphasised that the majority of Chinese construction firms operating in Africa have tended to be SOEs: China Overseas Engineering Corporation, China Road and Bridge Corporation, China Railway Construction, and so on. Consequently, they seem to gain significant government support, as part of official development assistance.

In order to win bids, these companies rely primarily on price competitiveness (30 per cent below those of their competitors) because of the low cost of labour 
and equipment they import from China. In addition, they often receive financial support from their government but sometimes international donors through multi-lateral and bi-lateral co-financing arrangements (World Bank, ADB, Kuwaiti Foundation). In Africa, the Chinese construction firms occupy second place with 21.6 per cent market share (2005 figure) behind the European groups with 49.3 per cent (Chen et al, 2009).

There are several projects managed by Chinese companies in the countries of ECCAS with financial support from the Exim Bank (Chen et al., 2009). It could be argued that Chinese construction groups across Africa operate primarily in construction (36.4 per cent), water supply (20.7 per cent), transport (13 per cent) and energy (9.8 per cent). The impact on the transfer of knowledge and expertise would be important if the Chinese groups had insured the implementation of the most advanced multi-partnership in order to fulfil the needs of the local partners in terms of transfer of technology and know-how (Dzaka, 2008).

With the exception of South Africa, local construction firms seem to be uncompetitive and thus pose no threat for Chinese companies, because of their low technical and financial capacity and their lack of skilled labour. This tends to limit Chinese incentive to enter into partnerships with these firms and therefore reduces the transfer of knowledge and expertise. Another point is the fact that the Chinese construction firms rely heavily on labour imported from China to carry out their various infrastructure projects in Africa on average 48 per cent of Chinese workers against 51 per cent of African workers and one per cent of workers from third countries (Chen et al., 2009). The imbalance is even more important if one examines the distribution of qualified personnel: the Chinese technicians occupy 91per cent of management positions, while their African counterparts occupy only eight per cent and technicians from third countries, one per cent. In the latter case, the available data indicates that the one per cent is constituted by highly skilled workers of engineering companies from the OECD and exercise technical control and work supervision to ensure compli- 


\section{AFRICAN \\ EAST-ASIAN \\ AFFAIRS \\ THE CHINA MONITOR}

ance with international standards. This is the case of the German firm Fichtner associated with the China National Machinery \& Equipment Import \& Export Corporation for the completion of the Imboulou hydropower in Congo - Brazzaville. One can also mention the case of Angola, where a German firm, Galfi Engineering, has been involved in the supervision and quality control of road construction carried out by groups such as Chinese China Road and Bridge Corporation.

In other infrastructure projects with high added value such as ICT, we find that not only do these groups maintain a majority stake but also the direction, namely the strategy of the joint-venture is also dominated by the Chinese partners, while local partners seem to exercise supervisory roles. This is the case for example of the mobile phone company China Telecom Congo (CTC) in the DRC which, since 2001, has been working with Chinese-owned ZTE who has a majority of 51 per cent, with the rest going to local public interest (Corkin, 2008).

The SOEs engaged in infrastructure projects in Central Africa are expected to increase the level of knowledge of the host countries through technology transfer. This strategy constitutes a channel to implement Chinese development aid. It requires a specific state intervention, including public-private partnerships through education and research and development (R\&D). Unfortunately, in the Republic of Congo and the DRC, the role of states in the area is so limited that these countries attract little in the promising sectors, with high value added or related to the knowledge economy (electronics, computers, telecom, ICT, biotechnology; and so on).

In Congo - Brazzaville, China Jiangsu International Economic Technical Cooperation, opened over the past years in partnership with the Department of Technical and Vocational Education, vocational training centres to compensate the shortage of local skilled workers and promote the employment of young people. In a US $\$ 8.5$ billion concessional loan concluded in 2007 between China and the $\mathrm{DRC}$, there is a specific clause in the agreement allowing Congolese workers to 
occupy 80 per cent of the workforce in all projects in order to fight endemic unemployment. Chinese have to train Congolese staff insuring that the transfer of technology is taking place and one per cent of the investment has to be spent on social operations in the area and around 11 per cent of the amount should be allocated to Congolese enterprises. Under these circumstances, three per cent has to be used to cover environmental costs.

\section{The impact of the financial crisis on Chinese FDI in Central Africa}

Our field investigations confirm that the financial crisis that erupted worldwide in 2008, has not fundamentally hampered the movement of Chinese FDI to Africa, particularly to countries richly endowed with natural resources, such as those of Central Africa. Milelli et al. (2009) point out that the global crisis has been accompanied with a slowdown in Chinese FDI to developed countries as this dynamic tends to be mainly motivated by market access. Consequently, a deployment of FDI to the countries richly endowed with minerals and hydrocarbons is expected. In this context, the natural beneficiaries should be in Africa and Latin America.

The Sino-African overall trade fell in 2009 compared to 2008 (US\$ 91 billion against US\$ 107 billion), even though the Chinese Ministry of Commerce (MOFCOM) announced that FDI to Africa has increased by 81 per cent for the first six months of 2009 compared to the same period in 2008, reaching US\$ 552 million (Brautigam, 2009).

As highlighted by Pairault (2010), the destination of FDI projects made by the Chinese public groups located in Africa, in 2009, tend to be the third largest in the world with 21.4 per cent of total projects, after Asia without Hong Kong (24.4 per cent) and Hong Kong (21.9 per cent) but ahead of Latin America (10.3 per cent), Europe (10.3 per cent), Pacific (6.4 per cent) and North America (5.3 per cent). In fact, the dynamics of Chinese FDI in Africa is fundamentally based on the commitment of public companies seeking access to natural resources in exchange for infrastructure projects as part of global solutions like Angola es- 


\section{AFRICAN \\ EAST-ASIAN \\ AFFAIRS \\ THE CHINA MONITOR}

tablishing a very close link between FDI, ODA and trade.

As Chinese imports from Africa consist mainly of raw materials with demand remaining relatively price inelastic, the solutions offered to African partners from China - raw materials against infrastructure - mean that the decline of African exports to China can only be limited in the short term due to severe financial crisis such as 2008. In the long term also, there should be only marginal reduction of Chinese FDI in Africa because the Chinese SOEs, which are the engine, are supported by a Chinese banking sector relatively unscathed by the financial crisis (Schiere, 2009).

China is trying to invest in Africa in order to diversify its economy and to increase its assets. In fact, the Asian giant is trying to diversify its foreign exchange holdings beyond the significant accumulation of US treasury bonds. Chinese companies tend to be encouraged by the policy of globalisation promoted by their government since 2001. They are seeking to exploit opportunities created by the crisis (falling prices of raw materials and depreciation of the shares of target companies) to operate in mergers and acquisitions. Another point is the fact that they seem to capture strategic assets and seize foreign groups already active in Africa, particularly in the extractive industries (energy and mining) and the banking sector. In this context, a state-owned enterprise, Aluminum Corporation China (Chinalco), for example, acquired a 12 per cent stake in Australian-British mining giant, Rio Tinto, which controls several subsidiaries in Africa in 2008 (Cook et al, 2009; Brautigam, 2009).

Under these circumstances the Industrial and Commercial Bank of China acquired billion a 20 per cent stake in South African bank Standard Chartered Bank for US\$ 5.4. The bank has subsidiaries in over twenty African countries, including in Central Africa. There is some evidence to mention that discussions between partners began in 2007 and shareholder approval was given in October 2008, fuelled by the pressure of the crisis. In this context, it is noteworthy, that China's investment in Central Africa has not been thwarted by the global crisis. 


\section{Box 1: The impact of the financial crisis on the mining sector: The case of the Katanga province}

Since the fall in copper prices on the world market, from US\$ 9000 per ton in August 2008 to just US\$ 3,200 at the beginning of 2009 (Financial Times, 2009) more than 40 copper smelters owned by micro and small Chinese private enterprises have closed. It is true that most of these smelters and trading houses are not identified and the World Bank (2008) estimated that out of 325 mining companies operating in Katanga, including the artisanal sector, only 10 per cent are quoted on international stock exchanges. It is known that some Chinese companies (examples include, Huachin, Congo Loyal Mining, and so on) started their mining operations in Katanga, beginning in 2005, following the visit to Beijing by President Joseph Kabila (RAID: Rights and Accountability in Development, 2009). It is understood that out of approximately $70-75$ foundries in the formal sector, in 2008, most plants were under control of Chinese entrepreneurs (World Bank, 2010: 36), but also to a lesser extent, Pakistani, Lebanese and Indian entrepreneurs (Jansson 2009: 37 and RAID 2009). For specialists in this sector, the DRC's foundries can produce one ton of copper for about US\$ 3,500 per ton. The Chinese bosses were forced to abandon their business due to bankruptcy and to leave the country in late 2008, only 10per cent have kept their factories in the Katanga region. On average each foundry employed 150 employees, resulting in the unemployment of more than 6,000 workers who received a monthly salary of US\$ 100 corresponding to the minimum wage in the DRC. In general, according to RAID (2009), 300000 jobs have been lost in the mining sector in Katanga, following the closure of 50 per cent of SMEs due to the financial crisis in late 2008.

In terms of mining in the DRC, there are two aspects relating to the activities of Chinese investors. The first one concerns the well-known mining project led by the Sino-Congolese Socomines Public groups involved in the mining and infrastructure sectors. The second part deals with mining concessions held by Chinese SMEs in partnership with local entrepreneurs. The latter often hold the mineral rights but lacked the capital for the operation of the concession, hence the partnership with private investors in China. Before the crisis, a large group of Chinese entrepreneurs was active in the mining province of Katanga and in the neighbouring province of North Kivu. These investors were operating mainly in mining, especially the melting of copper and cobalt, as well as the marketing of minerals, managing the brokerage (such as in Goma, the provincial capital of North Kivu). Thus, before the crisis, according to various authors (Jansson 2009:24; CCS 2010:75) near 5000 Chinese were living in Katanga province, including Lumbubashi, the provincial capital, against just 1000 immigrants in May 2009; most of these immigrant entrepreneurs (most of whom are small traders, like in other African cities) had to leave the country due to the global crisis and its impact on the DRC macro-economic environment (collapse of foreign exchange reserves, depreciation of the local currency: the Congolese franc, weak GDP growth and so on).

Finally, according to a recent study (CCS, 2010) it seems that no private player in the Chinese mining sector in DRC is supported by the Chinese government or public financial institutions. These Chinese enterprises therefore behave like all private companies seeking business opportunities.

Source: Based on field data and literature review 


\section{AFRICAN \\ EAST-ASIAN \\ AFFAIRS \\ THE CHINA MONITOR}

As highlighted by J. Jansson (2013), Chinese involvement in the DRC is currently experiencing some difficulties to sustain activities. In this context, Exim Bank pulled out of the project after offering approximately US\$ 1 billion in finance for infrastructure.

\section{Conclusion}

By the end of the day, it is wise to analyse to what extent Chinese investment in Central Africa could contribute to sustainable development and poverty reduction in host countries. One can mention that China needs to diversify its export markets as growth is driven by raw materials. The commitment of the Chinese SOEs, through long-term strategies with the support of the Chinese state seems to be the cornerstone of stability and sustainability of Chinese FDI in Central Africa.

In order to ensure the adequacy of Chinese FDI to the goals of sustainable development, countries should adopt a clear overall strategies vis-à-vis their partnership with China. Consequently, the Republic of Congo and the DRC must improve their political and economic governance.

The two main challenges related to the growing presence of Chinese FDI in these countries should be highlighted. The first challenge is to improve the management and the system of exploitation of natural resources including minerals and oil. In fact, it is expected to increase their attractiveness by accelerating the modernization of physical infrastructure and human capital to diversify their production base to support sustainable economic growth. This seems to be a sine qua non condition in order to build an autonomous framework integrating assimilation of knowledge as well public-private partnerships with China and other emerging countries especially India and Brazil.

These dynamics are significant to take into account when exploring the strategies of MNCs in Central Africa in order to establish how they tend to be different from the Western companies. In this context we need to identify trends in 
regional distribution of Chinese FDI, motives and strategies applied in the context of the Economic Community of Central African States (ECCAS).

\section{Bibliography}

Alden, C. and Davies, M. 2006. A profile of the operations of Chinese multinationals in Africa. South African Journal of International Affairs, 13 (1): 83-96.

Alden, C., Large, D. \& De Oliveira R.S (eds.). 2008. China returns to Africa. In Ferreira M.E. "China in Angola: Just a passion for oil?” Chap.15, p.295317.

Banque Mondiale. 2010. Diagnostic Trade Integration Study: Democratic Republic of Congo. Kinshasa, July, 201p.

Beuret, M. \& Michel, S. 2008. La Chine a -t- elle un plan en Afrique?. Afrique Contemporaine, 228:49-68.

Berthélemy, J.C. 2009. Impact of China's engagement on sectoral allocation of resources and aid effectiveness in Africa. Africa Economic Conference 2009, 11-13 November, ADB-ECA, Addis-Ababa, 30p.

Brautigam, D. 2009. Looking East: Africa's Newest investment partners. Emerging markets forum, September 13-15. Western Cape, www.emergingmarketsforum.org, p. 3-13.

CCS. 2010. Evaluation des engagements de la Chine en Afrique dans le cadre du FOCAC et cartographie des perspectives d'avenir. CCS, Janvier, Rapport préparé pour la Fondation Rockeffeller, 297p. www.ccs.org.za.

Chen, C., Chiu, P. C. Orr, R.J. Goldstein, A. 2007. An empirical analysis of Chinese construction firms entry into Africa. The CRIOCM 2007 Inter- 


\section{AFRICAN
EAST-ASIAN \\ AFFAIRS \\ THE CHINA MONITOR}

national Symposium on Advancement of construction management and real Estate. 8-13. August, Sydney.

Chen, C., Chiu, P.C., Orr, R.J., Goldstein, A. 2009. Local operations of Chinese construction firms in Africa. An empirical survey. The International Journal of Construction Management : 75-89.

Cheng, L.K. et Ma, Z. 2008. China's outward foreign direct investment. Paper presented at the Indian Statistical Institute, 12 December, www.isid.ac.in/ $\sim$ pu/seminar/12-12-2008-paper.doc.

CCS 2007. China's engagement of Africa: preliminary scoping of African case studies (Angola, Ethiopia, Gabon, Uganda, South-Africa, Zambia). Centre for Chinese Studies, University of Stellenbosch, November, 88, www.ccs.org.za

Cook, S. and Lam, W. 2009. The financial crisis and China: What are the implications for low income Countries?, Institute of Development Studies, University of Sussex, 16p.

Corkin, L. 2007. China's contribution to the development of African infrastructure through investment in extractive industries, AFRODAD, Occasional Papers, no. 8.

Corkin, L. 2008. China-Africa relations: the case of Angola, AERC, WP, www.aerc.org, $31 \mathrm{p}$.

Davies, M. et al. 2008. How China delivers Development assistance to Africa, www.ccs.org.za/downloads/china-dev-africa-sum.pdf.

Dussauge, P. 2010. Le rôle des alliances et coentreprises dans la multinationalisation des entreprises chinoises. Larçon, J-P (éd.), Les Multinationales chinoises, Paris, ESKA.

Dzaka-Kikouta, T. 2008. L'Aide publique au développement de la Chine aux pays pétroliers et miniers d'Afrique centrale : une béquille indispensable 
au renforcement de sa présence économique? Techniques Financières et Développement, 89:27-34.

Dzaka-Kikouta, T. 2009. L'Aide publique au développement de la Chine à l'Afrique Centrale et son impact sur le transfert de connaissances vers les pays d'accueil : une étude exploratoire. Les Cahiers de l'Association Tiers-Monde, 24(2009):127-142.

Dzaka-Kikouta, T. et Bitemo, X. 2010. Biens publics et capital social : l'impact du rôle économique de l'État sur l'attractivité du territoire des PVD. Cas des pays miniers et pétroliers d'Afrique centrale, to be published in Mondes en Développement.

Foster, V. et al. 2008. Building bridges: China's growing role as infrastructure financier for Africa. Washington, The World Bank/PPIAF.

Huchet, J.F. et Ruet, J. 2008. Les multinationales chinoises et indiennes à la conquête du monde" in Jaffrelot, C. (éd.), L'enjeu mondial : les pays émergents, Paris, FNSP, p. 209-220.

Hugon, Ph. 2009. Les changements des attractivités des pays et des territoires émergents dans le contexte de la crise mondial, $\mathrm{XXV}^{\mathrm{e}}$ Journées du Développement de l'ATM, Luxembourg, 3-5 juin, 21p.

Jansson, J. 2013. The Sicomines agreement revisited: prudent Chinese banks and risk-taking Chinese companies. Review of African Political Econo$m y, 40(135): 152-162$.

Jansson, J. 2009. Patterns of Chinese investment, Aid and Trade in Central Africa (Cameroun, the DRC and Gabon). CCS, August , 59p, www.ccs.org.za.

Milelli, C, Hay, F., Shi, Y. 2009. L'implantation des firmes chinoises en Europe, dernières tendances, ministère de l'Économie, de l'industrie et de l'emploi, Paris, 46p. 


\section{AFRICAN \\ EAST-ASIAN AFFAIRS \\ THE CHINA MONITOR}

Pairault, Th. 2010. L'investissement direct chinois et la crise, XXVI Journées du développement de l'ATM, Strasbourg, 2-4 june 2010.

Sumata, C. 2010. Parallel Market for Foreign Currency and Hyperinflation: The case of Congo-Kinshasa. International Journal of Trade and Global Markets, 3(1):115-131.

Sumata, C. 2008. Migrant remittances as a new source for development finance: The case of sub-Saharan Africa. OSSREA Bulletin, V(1).

Sumata, C. 2002. Migradollars and poverty alleviation strategy issues in CongoDRC. Review of African Political Economy (ROAPE), 93(NovemberDecember).

Sumata, C. 2001. L'Economie Parallèle de la RDC : Taux de Change et Dynamique de l'Hyperinflation au Congo. L'Harmattan, Paris, June.

Schiere, R. 2009. Impact of the financial and economic crisis on China's Trade, Aid and Capital inflows to Africa., Development Research Brief, no11:13.

Raid. 2009. Chinese mining operations in Katanga, DRC. Right and Accountability in Development, September, 45p.

Tsafack Nanfosso, R. 2008. Analyse de la coopération économique entre la Chine et l'Afrique. AFAC, Yaoundé, 7 November, 18p.

Wang, E. 2009. China's investment in Africa for copper production, IWCC Joint Meeting, Seoul, 11-13 May, Beijing AXIS, www.thebeijingaxis.com, 32p.

World Bank. 2008. Growth with Governance. Washington. www.worldbank.org. 